University of California, Hastings College of the Law UC Hastings Scholarship Repository

Faculty Scholarship

2014

\title{
Curriculum Developments in American Law Schools in the Twenty-first Century
}

Leo P. Martinez

UC Hastings College of the Law, martinezleo@uchastings.edu

Follow this and additional works at: https://repository.uchastings.edu/faculty_scholarship

\section{Recommended Citation}

Leo P. Martinez, Curriculum Developments in American Law Schools in the Twenty-first Century, 3 China-EU L.J. 43 (2014). Available at: https://repository.uchastings.edu/faculty_scholarship/1445

This Article is brought to you for free and open access by UC Hastings Scholarship Repository. It has been accepted for inclusion in Faculty Scholarship by an authorized administrator of UC Hastings Scholarship Repository. For more information, please contact wangangela@uchastings.edu. 


\title{
Curriculum developments in American law schools in the twenty-first century
}

\author{
Leo P. Martinez
}

Published online: 13 November 2013

(C) China-EU School of Law 2013

\begin{abstract}
The article begins with a brief history of legal education in the United States. Early legal education was a model that was theoretically based primarily on mentoring by practicing lawyers but was light in terms of substantive knowledge. Gradually the model evolved to the point where professional teachers, armed with casebooks, imparted knowledge in the way imagined by Christopher Columbus Langdell. Today, with many questioning the continued efficacy of the Langdell model, many law schools are experimenting with the model so as to adapt to a changing legal environment. There is some irony in these models in that many of them are heavily dependent on mentoring by lawyers in the guise of law professors. Still, the large point is that American legal education is not static. Rather, American legal education is changing and adapting to a different environment.
\end{abstract}

Keywords Legal education - Evolving legal education - History of American legal education · American law schools · Curriculum changes

\section{Introduction}

I begin by asking the reader's indulgence in allowing me to describe the evolution (a deliberately chosen word) of legal education. In its history, the United States has developed from a regime in which formal legal education was non-existent to one in which there is a highly structured system of legal education and accreditation. As a general proposition, it is only through an understanding of the past that we can address the future. My aim is to show this is demonstrably true in the case of legal education.

L. P. Martinez $(\bowtie)$

Albert Abramson Professor of Law at the University of California, Hastings College of the Law, University of California, 200 McAllister Street, San Francisco, CA 94102, USA

e-mail: martinez@uchastings.edu 


\section{A history of legal education in early America}

\subsection{The apprentice model}

In the United States, legal education has been the subject of evolution by trial and error. Early in the history of post-Revolutionary America some lawyers were selftaught, but the majority received their legal education through apprenticeships under experienced practitioners of the law. ${ }^{1}$ The apprentice system was the most common method of obtaining a legal education, owing to the complete absence of law schools in colonial America. ${ }^{2}$ This system, generally unavailable to women, permitted men to receive an education and practical experience. ${ }^{3}$

The apprenticeship method, in its various forms, produced prominent figures in American history. John Adams, our second President, provides a prominent example of an American lawyer-turned-president produced through the apprenticeship model. His path through legal apprenticeship involved significant scholarly study. Adams's first mentor was a leading Worcester, Massachusetts lawyer named James Putnam. ${ }^{4}$ He was drawn to the literature of the law, reading Coke, Fortescue, and "other monuments of the common law" which were essential preparatory materials for the bar. ${ }^{5}$ Adams took on a new mentor, Jeremiah Gridley, when he moved to Boston. ${ }^{6}$ Gridley was the Dean of the Massachusetts bar, under whom Adams engaged in a vigorous study of Roman-based civil law that would remain a lifelong intellectual pursuit. ${ }^{7}$ Adams recalled that Gridley's advice on the law was high-minded; that the study of law itself was the goal, not the pursuit of wealth. ${ }^{8}$

Thomas Jefferson, our third President and the architect of the US Constitution, offers yet another exceptional example of an American lawyer-president trained through apprenticeship. After graduating from The College of William and Mary, Jefferson turned to the study of law as an apprentice under an eminent attorney named George Wythe. ${ }^{9}$ Wythe guided Jefferson in practical matters, directed him to observe the General Court, and gave him considerable freedom in reading history, philosophy, and scientific works in addition to legal treatises. ${ }^{10}$ Perhaps Jefferson's view of legal education experience is summed up in his quip: "[a]ll that is necessary for a [law] student is access to a library, and directions in the order the books are to

\footnotetext{
1 Harno 1953, p. 19. There are a number of other excellent works which cover American legal education: Friedman 2005; Stevens 1983; Moline 2004; Katcher 2006.

2 Moline 2003, p. 780.

3 Ibid.

4 Wroth 2004, p. 7. In Adam's case, the relationship with Putnam was pursuant to a contract under which Adams agreed to study under Putnam's supervision for a period of 2 years. McCullough 2001, p. 44.

5 Ibid. p. 7.

6 Ibid.

7 Ibid. p. 8 .

8 Ibid. p. 44.

9 Ibid.

10 Ibid.
} 
be read." ${ }^{11}$ Such simplicity could only have come from one of the Framers of our Constitution.

Some 80 years later, Abraham Lincoln expressed essentially the Jeffersonian view of legal education. Lincoln said, "the cheapest, quickest and best way [to become a lawyer is to] read Blackstone's Commentaries..., get a license, and go to the practice and still keep reading." 12

Unlike Adams and Jefferson before him, Abraham Lincoln began his legal apprenticeship with no formal education beyond reading and writing. ${ }^{13}$ For the first 21 years of his life, in fact, Lincoln had only 1 year of formal education. ${ }^{14}$ Mindful of his ambitions of becoming a lawyer, Lincoln joined local debate clubs to refine his oral advocacy skills. ${ }^{15}$ His mentor was an Illinois "Justice of Peace" named Bowling Green, under whose guidance Lincoln attended trials and was allowed to practice in an informal capacity. ${ }^{16}$ Additionally, Lincoln was allowed to draw deeds and bills of sales for his neighbours during the course of his apprenticeship. ${ }^{17}$

In theory, an apprentice would spend several years learning the law as well as receiving practical experience. As the foregoing examples show, the accomplishments of some individual lawyers were nothing short of spectacular. Still, history does not well record lack of accomplishment and it is not surprising that the quality of education under the apprentice system varied tremendously with the skill and attention of the attorney providing instruction. ${ }^{18}$

There were four general characteristics of the apprentice system. First, it was cheap. Because apprentice Labor was cheap, apprentices could be used to fill a number of mundane though necessary functions. ${ }^{19}$ Second, instruction was uneven. It was uneven because apprentices were often relegated to menial tasks and because even the most capable lawyers could not be relied upon to dedicate an adequate amount of time to their apprentices' legal education. ${ }^{20}$ Third, and not surprisingly, the apprentice system was devoid of exposure to legal theory. ${ }^{21}$ Fourth, the lawyers produced by this system varied significantly in their abilities mainly because questions of competence were not addressed in any systematic way. ${ }^{22}$

Apart from the apprentices, the few self-taught lawyers fared worse in general and few of them achieved the level of competence necessary to adequately serve

\footnotetext{
11 Rhode 2000, p. 23, citing Jefferson's writings in Peterson (ed.) 1984, p. 966.

12 Katcher 2006, p. 343, citing Friedman 2005. As an aside, in his own way, Lincoln was tacitly supporting continuing legal education.

13 Hill 1906, p. 27.

14 Frank 1961, p. 10.

15 Hill 1906, pp. 28-29.

16 Ibid. pp. 29-30.

17 Ibid. p. 57.

18 Sonsteng et al. 2007, p. 322.

19 Ibid.

20 Ibid.

21 Ibid. p. 319.

22 Ibid. p. 322.
} 
their clients' needs. ${ }^{23}$ It was in this backdrop that a formal legal education system emerged.

\subsection{An intermediate step}

While the period from 1779 to 1870 saw considerable change in the delivery of legal education, quality was not significantly improved. The first law schools emerged in 1779 and Thomas Jefferson is credited with the founding of the first professorship of law at The College of William and Mary. ${ }^{24}$ In 1790, subsequent professorships of law were established at Brown College and at Benjamin Franklin's College of Philadelphia. ${ }^{25}$ Columbia followed suit in 1793 and Princeton in $1795 .^{26}$ These professorships were intended to instruct undergraduates in the study of law, a significant development reflecting the integration of law into American academia. ${ }^{27}$ Unlike the apprentice model, this early American undergraduate model of legal education concentrated primarily on teaching the theory of law as opposed to the practice of law. ${ }^{28}$ Still, beyond a very small cadre who taught law courses there was no real program of legal education as such.

Before these university courses evolved into full law departments, the emergence of independent "law schools" with no university affiliation developed as an intermediate step. ${ }^{29}$ The first schools dedicated exclusively to the law grew out of specialized law offices that employed several apprentices at one time. ${ }^{30}$ Some attorneys found that teaching law was a lucrative enterprise, or at the very least an intellectually rewarding experience, and thus spent more time with their apprentices and less on their law practices. ${ }^{31}$ The most successful, long-lasting, and well-known of these early law schools was the Litchfield Law School, which offered a curriculum that consisted of lectures on the legal theory of William Blackstone, with collateral reading and examinations on Saturdays, covering 14 months (with two four-week breaks). ${ }^{32}$

The first university affiliated law school, Harvard Law School, began operation in 1817. ${ }^{33}$ At this time, a law degree was not considered a post-graduate degree and it was not standard to require any college work from law students. ${ }^{34}$ Classes at

\footnotetext{
23 Ibid. p. 321.

24 Konig 2004, p. 20. Jefferson installed his former mentor Wythe as the first American professor of law. Ibid.

25 Stein 1981, p. 429, 442.

26 Ibid.

27 Ibid.

28 Ibid.

29 Moline 2003, p. 795.

30 Sonsteng et al 2007, p. 322.

31 Stein 1981, pp. 442-443.

32 Ibid. p. 443. Brian Moline observes that many of Litchfield's graduates achieved fame and distinction. Moline 2003, p. 796.

33 Sonsteng et al 2007, p. 322.

34 Ibid.
} 
Harvard consisted of lectures that demanded little from the students and offered little in terms of practical information and how to apply what was being taught. ${ }^{35}$ Structurally, legal education was still inconsistent. Like the apprentice model, how much the student learned depended heavily on the teacher. ${ }^{36}$ As noted above, there was no substantial increase in the quality of legal education.

\subsection{Christopher Columbus Langdell}

A new era of legal education occurred with the advent of Christopher Columbus Langdell's appointment as the Dean of Harvard Law School in $1870 .^{37}$ At the time of Langdell's appointment, a formal legal education lasted 18 months or less, and the curriculum consisted of ungraded, elementary courses, with no exams or attendance requirements. ${ }^{38}$ Under Langdell, legal education was elevated to a postgraduate subject lasting 3 years, the current American model. ${ }^{39}$

Langdell introduced entrance exams, graduation exams, rigorous coursework, and the "case method." 40 Langdell's innovative case method replaced textbooks with appellate cases arranged to illustrate the meaning and development of legal principles-essentially, he sought to introduce the scientific method to legal education. ${ }^{41}$ In classrooms, Langdell incorporated "Socratic dialogue" into discussions, engaging students in prolonged conversations that required them to distil the applicable rule of law from "superfluous" facts of the cases before them. ${ }^{42}$ Langdell believed that students should derive principles of law from the close study of original sources and develop their own analytical powers. ${ }^{43}$ Professor Ralph Michael Stein noted that "in a real sense, [Langdell's] method suggested an underlying respect for the law student as both [a] scholar and junior colleague." 44 Langdell's legacy persists in the structure of contemporary American legal education. $^{45}$

In reviewing the history of American legal education, I am reminded of an article by the Honourable Michael Kirby, a former Justice of the High Court of Australia. Justice Kirby wrote about Charles Darwin's explanation "that all living organisms need adaptation and variation to survive and to adapt to new times and

\footnotetext{
35 Ibid. pp. 322-323.

36 Ibid.

37 Moline 2003, p. 800.

38 Sonsteng et al 2007, pp. 324-325.

39 Ibid. p. 325.

${ }^{40}$ Ibid. See also Katcher 2006, p. 361.

41 Sonsteng et al 2007, p. 325.

42 Ibid.

43 Stein 1981, p. 449.

44 Ibid. p. 451.

45 Notwithstanding the emergence of professorships and proprietary law schools, apprenticeships remained the most common means of obtaining a legal education well into the 19th century. Moline 2003, p. 801 .
} 
circumstances." ${ }^{46}$ Although Justice Kirby was applying Darwin's principles to Australian judicial appointments, his observation about Darwinian survival applies equally well to the development of legal education in the United States prior to Langdell.

\section{Legal education development for the twenty-first century}

As American legal education has evolved since the founding of the Republic, we continue to adapt in order to survive in these changing times. A description of a few of the curriculum developments in American law schools today will illustrate the kinds of adaptation and innovation that is occurring in the twenty-first century. I describe six of the developments occurring recently at various law schools. In this respect I broadly group these developments in arbitrary categories that include integrated curriculums, foundational skills, professional partnerships, technology oriented clinics, bridge to practice programs, and technology in the classroom. These, and representative examples of each, are set forth below.

\subsection{Integrated curricula}

Some schools have adopted an integrated curriculum. For example, American University's Washington College of Law (WCL) has developed an Integrated Curriculum Program in an attempt to "highlight the interdependent nature of the curriculum and the practice of law." 47 The program, which WCL implemented in 1999, but was refreshed in 2009, offers team-teaching; sectional commons; ${ }^{48}$ panels presented by Deans' Fellows and faculty; peer mentoring; and substantive programs in fields that cross various subject matters. The faculty commons, where faculty members plan and implement supplemental programming designed to enrich the existing course content, and the team-teaching, where faculty members coordinate syllabi to emphasize synergies across subjects, are perhaps the most intriguing aspects of this program. ${ }^{49}$ In an additional effort to emphasize real-life lawyering skills, first-year students must take a course in Legal Rhetoric, where students engage in pre-litigation case planning; draft complaints, responsive pleadings, and interrogatories; and engage in negotiation and settlement. ${ }^{50}$

\footnotetext{
46 Kirby 2010, p. 18. The rest of the quote continues: "Reproduction by identical or near-identical cloning would endanger the capacity of the organism to cope with contemporary challenges, even perhaps to survive." Ibid.

47 Integrated Curriculum Dean's Fellows, American University of Washington, College of Law http:// www.wcl.american.edu/icdf/ (Accessed 29 May 2013).

48 Sectional commons are intended to be discussions on current events, such as Supreme Court cases, elections, and options at the school, that are led by various faculty members. The school hosts between two and four commons each semester, allowing professors to engage students in topics outside the course syllabi. Ibid.

49 Abrams 2010, p. 438.

50 Ibid. pp. 442-444.
} 


\subsection{Foundational skills}

Some schools have returned to fundamentals in the shape of a foundational skills orientation. In 2012, The University of North Dakota (UND) revamped its curriculum to focus more on foundational knowledge and skills; ethics and professionalism; leadership, collaborative, and adaptive skills; and service to society. Each course in the updated curriculum must include instruction in and an assessment of an ethics or professionalism issue, as well as a writing assignment. Beginning in Spring 2014, UND will begin offering a two credit class, Professional Foundations, that will offer students the ability to "cultivate a reflective mindset and the habits of being that are vital to the development of professional identity and the exercise of sound professional judgment." 51 The class will focus on the fundamentals of professional roles and identities, the lawyer-client relationship, and an exploration of practice environments. The course will be taught by a team of faculty members. The team approach is intended to expose students to a myriad of options and ensure a diverse educational experience.

\subsection{Professional partnerships}

Other schools, including the University of Kansas School of Law (Kansas), the University of Miami School of Law (Miami), and the University of California, Hastings College of the Law (UC Hastings), have partnered with other professional schools to enrich their curricula. Each of these schools offers medical-legal clinics that provide students with hands-on experience addressing a wide range of issues pertaining to health law. In each case the law schools are taking advantage of the proximity and association with a prominent medical school. Kansas's MedicalLegal Partnership Clinic is a collaboration between the School of Law and the Department of Family Medicine at the University of Kansas Medical Center. ${ }^{52}$ The clinic not only provides free legal assistance to low-income patients at the hospital, it also affords Kansas students the opportunity to conduct intake interviews, develop case strategies, conduct legal research, prepare legal documents, and provide representation in administrative hearings and court (where permitted). Student participants bring their services to the community, doing in-home visits and assisting those who have not sought medical attention because of immigration issues or lack of insurance. ${ }^{53}$

Similarly, Miami students have the opportunity to participate in the Medical Legal Partnership (MLP) in collaboration with the University of Miami Miller School of Medicine, through the Health Rights Clinic. Students become members of

\footnotetext{
51 Professional Foundations: An Innovative Component of the First-Year Curriculum, University of North Dakota, School of Law http://law.und.edu/students/general/profound.cfm (Accessed 29 May 2013).

52 Medical-Legal Partnership Clinic, The University of Kansas, School of Law, http://www.law.Kansas. edu/mlpclinic (Accessed 10 October 2013).

53 KU Medical, Law Student Collaboration Expanded, Kansas News Service (8 February 2013), http:// www.news.Kansas.edu/2013/02/08/Kansas-medical-law-student-collaboration-expanded. (Accessed 10 October 2013).
} 
the healthcare team and assist patients with their legal issues. ${ }^{54}$ Participants function as the client's primary advocate in all aspects of the client's case, including interviewing and counselling, fact investigation, drafting and filing briefs, and participating in negotiations and hearings. ${ }^{55}$

Likewise, UC Hastings' students have the opportunity to participate in the Medical-Legal Partnership for Seniors Clinic in collaboration with the University of California, San Francisco (UCSF). ${ }^{56}$ Hastings students develop key lawyering skills through representation of low-income elderly patients at a UCSF medical clinic. Through the clinic, students are exposed to transactional lawyering skills, including drafting advance health care directives and simple wills, and advising patients on their eligibility for public benefits. 57

\subsection{Technology oriented clinics}

Similar to the law schools taking advantage of their proximity to high calibre medical facilities, others are also taking advantage of their proximity to unique resources. In the San Francisco Bay Area, for example, law schools are capitalizing on their proximity to Silicon Valley. For instance, students at Berkeley Law have the option to participate in The Samuelson Law, Technology and Public Policy Clinic. ${ }^{58}$ The Clinic trains students in public interest work pertaining to technology, intellectual property, privacy, free speech, and other related issues. In offering this Clinic, Berkeley is aiming to "support the public interest in technology law and policy, and to teach law students through real-world work, with live clients, on cutting-edge policy issues." In the past, students have worked with The Electronic Frontier Foundation, ACLU of Northern California, Center for Democracy and Technology, and The Mozilla Foundation, among other organizations at the forefront of law and technology policy. ${ }^{59}$ The Clinic, which was established in 2001, functions as a traditional legal clinic and as a think-tank of sorts. ${ }^{60}$

Santa Clara Law is also taking advantage of its location by providing students with the opportunity to learn about the functioning of lawyers at high-tech

\footnotetext{
${ }^{54}$ Health and Elder Law Medical Legal Partnership, Educating Tomorrows Lawyers, http://educating tomorrowslawyers.du.edu/course-portfolios/health-and-elder-law-medical-legal-partnership (Accessed 29 May 2013).

${ }^{55}$ Health Rights Clinic, University of Miami, School of Law, http://www.law.miami.edu/clinics/healthrights/ (Accessed 10 October 2013).

${ }^{56}$ Medical Legal Partnership for Seniors Clinic, UCSF/UC Hastings Consortium on Law, Science and Health http://ucsfconsortium.uchastings.edu/clinical/medicallegalpartnership/index.php (Accessed 10 October 2013).

${ }^{57}$ See Span P (2013) The Doctor's New Prescription: A Lawyer, New York Times, 31 March http:// newoldage.blogs.nytimes.com/2013/03/21/lawyers-join-a-seniors-clinic/\#more-14910 (Accessed 10 October 2013).

${ }^{58}$ Samuelson Law, Technology and Public Policy Clinic, Berkeley Law, www.law.berkeley.edu/ samuelsonclinic.htm (Accessed 25 June 2013).

${ }^{59}$ Ibid.

${ }^{60}$ About, Samuelson Law, Technology \&Public Policy Clinic, www.law.berkeley.edu/4431.htm, (Accessed 25 June 2013).
} 
companies through the Civil Practice, High Tech, and Social Justice Externship. ${ }^{61}$ While an extern, students work under the direct supervision of a California licensed attorney. ${ }^{62}$ This externship counts towards the High Tech Certificate, offered as part of Santa Clara's High Tech Law Institute. The institute has one of the largest intellectual property and high tech curricula in the country. ${ }^{63}$

Further, this year Stanford Law will launch the Juelsgaard Intellectual Property and Innovation Clinic. ${ }^{64}$ The core vision of the Clinic is "that intellectual property and law and the regulatory climate must be developed with acute sensitivity to the ways in which laws and regulations can serve to promote or frustrate vital innovation." 65 Students in the Clinic will represent primarily nongovernmental organizations in biotechnology, information technology, pharmaceuticals, clean technology, and the creation and distribution of knowledge under the supervision of Clinic instructors. ${ }^{66}$

At my own institution, UC Hastings' students can participate in a Technology Startup Clinic, part of the Innovation Law Clinics (ILC). The goal of the ILC is to "teach students how to become partners in enterprise... because the best business lawyers are those who understand the incentive structures that drive business organizations outside of and in addition to the legal regimes." ${ }^{\prime 67}$ While participating in the clinic, students work with private law firms and entrepreneurs in the very early stages of business planning to work on real startup company issues. The Technology Startup Clinic provides students with a unique opportunity to understand and address the legal issues facing startups, an important area of growth in the Bay Area.

\subsection{Bridge-to-practice programs}

Some schools have implemented "bridge-to-practice" programs in which third-year students, or even recent graduates, may apply for a defined term project with an approved employer for the opportunity to enhance their practical legal skills. UC Hastings, for example, has partnered with governmental organizations and legal nonprofits to create two-year fellowships encompassing law students' final year of law school and their first as new attorneys through a newly created not-for-profit

\footnotetext{
${ }^{61}$ Civil Practice, High Tech, and Social Justice Externship I, Santa Clara Law, http://law.scu.edu/ courses/civil-practice-high-tech-and-social-justice-externship-i/ (Accessed June 25, 2013).

62 Ibid.

${ }^{63}$ High Tech Law Institute, Santa Clara Law, http://law.scu.edu/hightech/ (Accessed 25 June 2013).

64 Juelsgaard Intellectual Property and Innovation Clinic, Stanford Law, http://www.law.stanford.edu/ organizations/clinics/juelsgaard-intellectual-property-and-innovation-clinic (Accessed 25 June 2013).

65 Romero J (2013) Phillip Malone to Direct New Juelsgaard Intellectual Property and Innovation Clinic at Stanford Law School, Stanford L. Blog, 13 May http://blogs.law.stanford.edu/newsfeed/2013/ 05/13/phillip-malone-to-direct-new-juelsgaard-intellectual-property-and-innovation-clinic-at-stanfordlaw-school/ (Accessed 10 October 2013).

66 Ibid.

67 Technology Startup Clinic, University of California, Hastings College of the Law, http://www. uchastings.edu/academics/clinical-programs/clinics/technologystartup/index.php (Accessed 24 June 2013).
} 
Lawyers for America. ${ }^{68}$ Participants work at a partner legal office full time and attend a classroom component as well.

In a similar vein, this summer the Sandra Day O'Connor College of Law at Arizona State University (ASU) will be launching the ASU Alumni Law Group, a teaching law firm that will hire and mentor recent graduates of the law school. ${ }^{69}$ The Law Group, modelled after a teaching hospital, will be a stand-alone, nonprofit firm that will help prepare new and recent graduates to practice law. The firm will focus its services on those who cannot afford to pay current market rates and will use graduates supervised by experienced attorneys. ${ }^{70}$

A recent report from the New York City Bar Association (NYCBA), a body independent of the law schools, has recommended that other schools implement similar pilot programs. ${ }^{71}$ If nothing else, this demonstrates that what UC Hastings and ASU are doing has currency in the profession.

\subsection{Technology in the classroom}

Still other schools have adopted innovative ways to use technology in the classroom, expanding student opportunities. For example, the Virtual Classrooms at North Carolina Central University (NCCU) School of Law employ synchronous learning, real-time or live-distance learning from remote or separate locations. ${ }^{72}$ The Virtual Classrooms, which feature an actual teaching space, were built in response to the school's distance-education program. In addition to using Panopto, software that records lectures and allows students to access them when convenient, the program features real-time video interaction between the professor and students regardless of their location. ${ }^{73}$ The Dean of the law school has expressed hope that the Virtual Classrooms will expand the budding environmental law partnership with Vermont Law School. ${ }^{74}$

Drexel University's Law School is also attempting to address the challenges of today's legal education through LawMeets, an online, interactive teaching tool. LawMeets is "a virtual sandbox for law students to learn through real-world experiences." 75 The program, currently being expanded, allows users to video

\footnotetext{
68 About Lawyers for America, University of California, Hastings College of the Law http://www. uchastings.edu/academics/clinical-programs/lawyers-for-america/index.php (Accessed 29 May 2013).

69 ASU News (2013) College of Law to Launch Teaching Law Firm in Summer, [business, culture \& affairs] 7 March, https://asunews.asu.edu/20130307_lawteachingfirm (Accessed 10 October 2010).

${ }^{70}$ It is envisioned that the firm will hire about 10 ASU law graduates per year for a total of 30 associates at a time. Ibid.

71 NYCBA 2013.

72 NNCU News (2010) NCCU School of Law Unveils Virtual Classroom, 30 July http://www.nccu.edu/ news/index.cfm?id=23a17f9c-19b9-b859-78d8d281313c2e54 (Accessed 10 October 2013).

73 Ibid.

74 Ibid.

75 Zahorsky RM (2013) Drexel University's Law School Takes Practical Training Online with LawMeets Course, American Bar Association Law Journal, 1 January http://www.abajournal.com/magazine/article/ drexel_universitys_law_school_takes_practical_training_online_with_lawmeets/ (Accessed 10 October 2013).
} 
themselves acting out responses to client-based legal scenarios that are reviewed by other participants. Users eventually gain access to an expert's response. ${ }^{76}$ The platform offers online courses that can be adopted in whole or modified by professors.

Students at the University of Miami School of Law also have access to cuttingedge technological learning tools, specifically LawWithoutWalls. ${ }^{77}$ LawWithoutWalls, a "part virtual educational collaboratory," brings together various institutions from around the world in an attempt to eliminate barriers between the participants (even those as far away as Shenzhen). ${ }^{78}$ Students develop a Project of Worth designed to solve an identified problem in legal education or practice. Students take part in Virtual Thought Leader Sessions where experts share their perspectives on desired changes in legal education and practice, and mentor the students. $^{79}$

The few examples described above, and numerous others that time does not allow me to mention, show that American law schools are responding, and adapting, to a changing environment in ways that is tailored to their circumstances. Darwin would be proud.

\section{Conclusion}

Unlike the apprentice model, the developments I've outlined are not cheap. At the same time, all have real potential to improve legal education, legal theory is a common denominator in each, and the final product — the output-is more likely to be better than not. This may even produce another Adams or Jefferson or Lincoln.

It is in no small sense ironic that the United States, which long ago shed the apprenticeship model of legal education, has, through the many developments outlined above, returned in part to an apprentice model of legal education with emphasis on mentoring and the realities of the practice of law in the twenty-first century. Clearly a desirable aspect of the apprentice system was it's mentoringmany apprentices had ready access to capable mentors from whom they could learn substance and to whom they could address questions. ${ }^{80}$ Many of the developments outlined above incorporate mentorship as an important facet of the initiative. The difference, of course, is that today's mentors are professionals-this is as it should be if the model is to work in any meaningful sense. ${ }^{81}$

\footnotetext{
76 Ibid.

77 LawWithoutWalls, University of Miami, School of Law http://www.law.miami.edu/academics/lawwithout-walls.php (Accessed 30 May 2013).

78 About, Law without Walls http://www.lawwithoutwalls.org/about/ (Accessed 30 May 2013).

79 Ibid.

${ }^{80}$ Despite the shortcomings of the apprentice system, there were many lawyers who sincerely wanted to train their apprentices properly. These included Tehophilus Parsons and Lemuel Shaw who had rules that governed the conduct and training of their students; indeed, Shaw's office became a "small private school for lawyers." Friedman 2005, p. 238.

81 It should also not be lost that even Jefferson's approach, to include science reading in the learning of the lawyer's craft, is effectively part of the technology oriented clinics.
} 
In his recent thought-provoking book Tomorrow's Lawyers Richard Susskind has tried to prepare us for, or at least warn us about, the sea changes to the profession. ${ }^{82}$ While Susskind admits that his prognostications may not accurately capture all the details, he is sure that change will come and the unprepared will suffer. He is likely right. Darwin's shadow looms over us. Whatever change we face requires some sort of adaptation. ${ }^{83}$ As the foregoing shows, American legal education is not static. Rather, American legal education is changing and adapting to a different environment.

Acknowledgments I thank President Huang Jin of China University of Political Science and Law and both Dean A.W. Heringa and Dean Liu Fei of the China-EU School of Law at the China University of Political Science and Law for the opportunity to make the presentation at the China-European School of Law at the China University of Political Science and Law Conference on Legal Education: twenty-first century Developments and Perspectives that formed the basis of this article. I am also grateful for the diligent research assistance and sharp editorial eye of Emily Goldberg, UC Hastings class of 2015. Despite all her efforts, errors are entirely mine.

\section{References}

Abrams JR (2010) A synergistic pedagogical approach to first-year teaching. Duquesne Law Rev 48(2):423-453

Frank JP (1961) Lincoln as a Lawyer. University of Illinois Press, Urbana

Friedman LM (2005) A history of American Law, 3rd edn. Simon \& Schuster, New York

Harno AJ (1953) Legal education in the United States. Bancroft-Whitney Company, San Francisco

Hill FT (1906) Lincoln the Lawyer, century, New York, published in 1996 by The Legal Classics Library, New York

Katcher S (2006) Legal training in the United States: a brief history. Wisconsin Int Law J 24:335-375

Kirby M (2010) Appointment to final national courts: lessons from Charles Darwin. Natl Law Sch India Rev 22:17-34

Konig DT (2004) Thomas Jefferson: The Lawyer as President. In: Gross N (ed) From law office to Oval Office. America's Lawyer Presidents, Northwestern University Press \& the American Bar Association Museum of Law, Evanston, Illinois

McCullough D (2001) John Adams. Simon \& Schuster, New York

Moline BJ (2003) Early American legal education. Washburn Law J 42:775-802

NYCBA (2013) Task force on new lawyers, employer partnerships and practice-orientated training working group: objectives, issues, conclusions and suggested pilot programs, May 14 (unpublished working paper)

Peterson MD (ed) (1984) Thomas Jefferson: writings. Literary Classics of the United States, New York Rhode DL (2000) Legal Education: professional interests and public values. Indiana Law Rev 23:38-45 Sonsteng JO et al (2007) A legal education renaissance: a practical approach for the twenty-first century. William Mitchell Law Rev 34(1):303-472

Stein RM (1981) The path of legal education from Edward I to Langdell: a history of insular reaction. Pace Law Faculty Publications, New York, pp 429-454

Stevens R (1983) Law school: legal education in America from the 1850s to the 1980s. The University of North Carolina Press, Chapel Hill

Susskind R (2013) Tomorrow's lawyers. An introduction to your future. Oxford University Press, Oxford Wroth LK (2004) John Adams: patriot lawyer. In: Gross N (ed) America's Lawyer-Presidents: from law office to Oval Office, Northwestern University Press \& the American Bar Association Museum of Law, Evanston, Illinois

\footnotetext{
82 Susskind 2013.

83 Susskind mentions other schools that are also changing their curricula to adapt. Ibid. p. 138 (mentioning Michigan State University and Harvard University in addition to the University of Miami).
} 